\title{
LITERATURE
}

DOI https://doi.org/10.30525/978-9934-26-110-7-10

\section{АСПЕКТИ ПАТРІОТИЧНОЇ СВІДОМОСТІ У ПОВІСТІ БОРИСА ГРІНЧЕНКА «СОНЯЧНИЙ ПРОМІНЬ»}

\author{
Вовк О. В. \\ кандидат філологічних наук, \\ дочент кафедри української літератури та теорії літератури \\ Дрогобицький державний педагогічний університет \\ імені Івана Франка \\ м. Дрогобич, Львівська область, Украӥна
}

Твори Б. Грінченка актуалізують ті чи інші аспекти патріотичної свідомості, виявляють та поборюють прояви антинаціонального чи маргінального світобачення й, тим самим, впливають на формування патріотичного світогляду дітей, підлітків, юнацтва. У такий спосіб художньо реалізується концепція національного звільнення, для якої, за I. Франком, найважливішими знаряддями $є$ «національна свідомість», «почуття солідарності» та «почуття сили і віри в остаточний успіх» $[2$, с. 376]. Однак найбільш художньо багатогранним, ідейно комплексним, наймасштабнішим твором у цьому зв'язку варто вважати повість «Сонячний промінь» [1, с. 323 - 447], написану у 1890 р. і вперше опубліковану через рік у журналі «Зоря».

Варто відзначити, що повість цілком можна віднести до синкретичного реалізму. У ній поєднуються тенденційно-реалістичні та критично-реалістичні змістово-стильові елементи із елементами просвітництва (однією із наскрізних ідей твору $є$ просвіта і праця інтелігенції для народу), романтизму (особливо це простежується у зображенні виняткових рис характеру студента Марка Кравченка) та сентименталізму (зворушливі описи хвороби та поступового згасання Катерини). Таке стильове розмаїття робить твір багатовимірним, жвавішим, доступнішим для сприймання передусім старшими дітьми й молоддю. Воно не дає ідейності витіснити естетичність, перетворити художню тканину на одноплощинну політичну пропаганду, а складні 
характери та проблеми спростити до редукованих публіцистичних гасел і закликів.

Іншим важливим значеннєвим аспектом повісті $\epsilon$ iï проблемна поліфонічність (від особистих до суспільно значущих питань національного та соціального спрямування), у межах якої домінує чітко окреслена національна проблематика. Ці національні проблемні аспекти перегукуються з іншими творами письменника на патріотичну тематику.

Чимало місця у повісті відведено зображенню типових характерів псевдопатріотів, що оточують головних персонажів. Насамперед - це більша частина гуртка українофілів, особливо старша: професор Човгань, Тапчанський, багатій Савчевський та ін. Письменник показує на їхньому прикладі роботу старших громад: нездатність до активної діяльності, брак чітких культурно-політичних орієнтирів, непродуктивна балаканина (постійні суперечки про мову), боягузливість. Однак у повісті чітко проступають й позитивні характери свідомих селян (хлопчика Корнія, його батька, сусідів і знайомих, що спраглі українського книжкового слова) та українофільської інтелігенції, діяльної, сміливої, бойової (передусім молоді).

Особливо близькими й доступними для свідомості юного реципієнта робить письменник змістові аспекти повісті, через введення любовної інтриги. Це завжди цікаво молодому читачеві. Йдеться про наскрізне драматичне кохання між головними героями - сином бідного міського чоботаря, студентом (згодом вчителем гімназії та секретарем у міському часописі) Марком Кравченком та спочатку малоросійською панянкою, а згодом переконаною українофілкою, сільською вчителькою Катериною Гординською. Розвиток кохання двох молодих людей не просто утворює основну сюжетну лінію повісті, разом з нею пов'язуються дві важливі взаємопереплетені проблеми твору, що художньо конкретизують смислові аспекти етнокультурного закорінення, національної ідентифікації, морального вибору. Перша стосується можливості поєднання інтимно-особистого (любові) та суспільного (національної справи). Друга - можливості індивідуального національного відродження дерусифікації (Катерина, меншою мірою Марко та ін.).

Найбільш фундаментальний націоналізуючий вплив на свідомість Катерини, як свого часу і на Марка, має поезія Т.Шевченка. Образи Кобзаря допомагають дівчині збагнути, як можна «зрекатися з-за любові до рідного краю» (самовідданість Марка вона порівнює з Гонтою). Так 3'являється усвідомлення суті образу патріота-борця: «Образи, найбільш образи опанували іiі. I один з їх був образ борця за рідний край, людини, що зрекається власного щастя. I той образ був перед нею тепер у 
надзвичайному сяєві» [1, с. 406]. Катерина цілковито змінюється, вона починає глибше розуміти світ внутрішній і зовнішній світ, починає розуміти, що «краса душі» - вища за фізичну вроду, що $є$ «дещо вище від задовольнення власних почуваннів та бажаннів» [1, с. 406].

Перемагаючи спротив батьків, Катерина вибирає долю сільської вчительки, та, на жаль, через утиски сільського начальства захворює на сухоти. Приїзд Марка, їхнє примирення i порозуміння, а згодом i одруження змушують хворобу відступити, однак ненадовго.

Над могилою коханої Марко подумки виголошує зворушливий монолог - звертання до померлої Катерини. Він утворює епілог повісті і має не лише психологічно-естетичне значення - його важлива художня функція - показати молодому читачеві послідовність та чіткість ідейної позиції персонажа й тим самим максимально наблизити його до патріотичних ідеалів українства. За допомогою монологу автор наголошує на ідеї несмертельності («Вся душа твоя чиста перелинула 3 останнім твоїм зітханням у мою душу і навіки з'єдналася з нею...») та метафорично зображає сенс життя справжнього українського інтелігента - «бути людям сонячним променем»: «...Сонячний промінь... Ти так завсіди любила сонце, що тобі сподобається се порівняння - я знаю. Чи не в цьому ж і мета людського життя - бути людям сонячним променем і робити їх щасливими...» [1, с. 447].

\section{Література:}

1. Грінченко Б.Д. Твори : в 2 т. / Борис Дмитрович Грінченко. Т.1. Поетичні твори. Оповідання. Повісті / упоряд. В.В. Яременка; приміт. А.Г.Погрібного, В.В. Яременка; вступ. ст. і ред. тому А.Г. Погрібний. К.: Наук. думка, 1990. 640 с.

2. Франко I. Нарис історії українсько-руської літератури до 1890 p. 3 останніх десятиліть XIX в. / Іван Франко. Дрогобич : ВФ «Відродження», 2008. 464c. 